\title{
Platform Business Models - A Case Study of the Technology Industry
}

\author{
Carmen-Alexandra Stoian ${ }^{1} \&$ Dragos Tohanean ${ }^{2}$ \\ ${ }^{1}$ Accounting, Bucharest University of Economic Studies, Romania \\ ${ }^{2}$ Business Administration, Bucharest University of Economic Studies, Romania \\ Correspondence: Carmen-Alexandra Stoian, Accounting Doctoral School, Bucharest University of Economic \\ Studies, Romania.
}

Received: February 4, 2021; Accepted: March 8, 2021; Published: March 8, 2021

\begin{abstract}
The opportunity to create a value exchange environment is uniquely offered by the platform businesses. A novel approach of co-creating value is writing the rules in the platform business world. This paper analyzes the platform business models within the technology industry based on a multiple case study. As the main driver of business performance in this environment is technology, companies are using it to develop new products or to provide technology as a service. Thus, the main objective is to debate on the actual business needs in terms of business model innovation and to investigate how platform business models are developed through strategic acquisitions to achieve competitive advantage. The cases analysis suggests that technology acquisitions made around the core business may contribute to business model innovation. In addition, new partnerships with the external environment may facilitate mutual value creation exchanges and the platform may evolve through adding extra features from its external partners. We contribute to the advancement of business model research by putting platform business model study into the competitive context of the technology industry, with findings on how platforms are used in the digital era to innovate the core business model. From a practitioner's perspective, this study may help companies to understand the importance of investing in other technology companies and to identify the opportunities of business model innovation through strategic partnerships. The limitation of this study is that the main data used for the multiple case study was derived from secondary sources and it provided insights about each company's platform business model from a macro perspective.
\end{abstract}

Keywords: platform business model, technology industry, business model innovation, technology acquisitions

\section{Introduction}

Digital era offers both opportunities and challenges for the companies from the technology industry, the increased number of platform businesses being accelerated by digitization trends. The year of 2021 is bringing several strategic opportunities within the technology industry and companies can take advantage of them in order to build strong recovering strategies after the Covid-19 crisis. They need to ramp up their digital transformation initiatives to build a better cloud infrastructure, enhance the cybersecurity strategies and transform their business models (Deloitte, 2021). Five tech companies: Microsoft, Apple, Amazon, Google, and Facebook led the market as being the largest US public companies by market capitalization (Press, 2018). There is a strong pressure on technology companies to stay on top. New technological innovations such as cognitive computing and digital reality are reshaping the business world. Several market changes such as re-platforming, digital talent acquisition and cyber resilience are strongly influencing the future of organizations (DXC.Technology, 2021).

The study of the platform business model became a topic of even greater interest due to the context of Covid-19 pandemic. This global health crisis forced companies to accelerate the digital transformation process and people to live exclusively in the digital world. Therefore, the practical importance of this topic is a motivating factor of the present study that aims to focus on the value creation process of different digital platforms. The implications of this study are directed towards both the field of academic research and business reality. One of this crisis's outcomes is that companies will get through different phases, from 'respond' to 'recover' states, and this will lead to a new age of innovation in which the technology strategies will instinctively change. A growing body of literature in innovation management recognizes different ways of creating value through platforms (Gawer and Cusumano, 2014; de Reuver et al., 2017; Karhu and Ritala, 2020). The platform business model is also becoming a key point of interest to many practitioner publications that presents successful platform strategies from the business reality (Accenture, 2016; KPMG, 2020; McKinsey Quarterly, 2019; Deloitte, 2020; Forbes, 2020). However, even if this research area progresses rapidly, there are many characteristics that need to be defined and 
analyzed. The emergence of platform businesses led to a new economy development called the sharing economy (Li et al., 2017). A strategic question for technology companies to consider is how they can expand their business portfolio. A potential valid answer could come from companies' choices to acquire new business or to create new partnerships. As the new approach of value creation within the sharing economy is to co-create, the digital environment begins to change the business leaders' mindsets and they have now started to invest more in other businesses in order to integrate new capabilities and innovations into their existing business models (KPMG, 2020).

The present paper's main objective is to debate on the actual organizational needs in terms of innovating a platform business model. Therefore, this study will investigate several strategic decisions through different business acquisitions that may have the potential to influence the long-term direction of a company. The structure of this paper includes a summary of the available literature on business models which integrates the new concept developed from this literature stream, namely the platform business model. Previous studies related to business model innovation are also considered. The methodology highlights the practicability of a multiple case study and addresses the criteria for the company cases selection. Developing insights on software, hardware, infrastructure, e-commerce or social media platform business models, this study will draw conclusions on how the technology industry has the power to reshape the new world of business through building entire ecosystems around several technology-based products and services.

\section{Review of the Literature}

The world of digital platforms has been created around the new technologies that introduced new ways of doing business at lower costs that are enabling different interactions between different sides of the market (Eckhardt et al., 2018; Parker and Van Alstyne, 2018; Teece, 2018). Artificial intelligence, augmented reality, blockchain, drones, internet of things, robots, 3D printing or autonomous vehicles are rewriting the rules of business and innovation. These new technologies have an incredible power to transform entire businesses. For example, artificial intelligence may enhance productivity and GDP potential of the global economy, due to its capacity to bring a significant product variety and generate personalized services in the market ( $\mathrm{PwC}$, 2017).

There are essential research areas developed from the strategic management literature that include the main dimensions studied around the business model: change and evolution, innovation, performance and controlling and design (Wirtz et al., 2016). The customer value proposition, profit formula, the resources and processes are presented in the literature as key concepts that define a business model (Johnson et al., 2008; Zott et al., 2011). The value proposition is generally the way of creating value for customers and concerns the decisions about the nature of products or services delivered (Morris et al., 2015). The profit formula defines how the company is creating value for itself while delivering the value to its customers. It is often presented in the literature as the revenue model, the structure of costs, the margin model or through resource velocity (Johnson et al., 2008). In terms of resources, a business model identifies the key assets such as people, technologies, equipment, channels, and brands that are needed for the company to provide value to its customers. Finally, processes refer to the operational and managerial activities that ensure the organizational growth (Casadeus-Masanell and Ricart, 2011). The business model is defined in the literature as the concept that has the potential to explain through an integrated approach how companies are doing business (Zott et al., 2011; Afuah, 2004). Several authors proposed different frameworks that include the business model characteristics. For example, Morris et al. (2015) identifies a sixcomponent structure that aims at presenting how a business model works, regardless of the maturity level of the company. In addition to the classic components such as the value proposition and key competence sources like business processes, market factors including targeted customer characteristics and competitive strategy factors such as product or service quality, innovation leadership and customer experience are being identified. Furthermore, besides this research trend of analyzing the business model components, investigations have been conducted also on the relationship between the business model and the business strategy. On one hand, the business model refers to the company's logic to create and capture value for stakeholders, while on the other hand the strategy is seen as the distinctive plan that positions the company in the market (Casadesus-Masanell and Ricart, 2011). These research perspectives have led researchers in the field to further study the role of such models for a company. Osterwalder and Pigneur (2005) identifies several functionalities that improve the business management, enhance the business model design, planning, and its implementation as well as the alignment of strategy with new digital technologies within the corporate governance of a company. In addition, it may help describe the prospects of a company and help promote innovation initiatives through the development of competitive strategic products or services (Rasmussen, 2007; Boons and Freund, 2013).

As the new trend is to co-create value through the business model, platforms are gaining great popularity as companies are getting engaged in new collaborative operations and networked systems (Romero and Molina, 2011). Different perspectives from technology management or economics built the foundation for a new research 
area regarding the business platforms. On one hand, following an economic way of thinking, platforms are predominantly debated observing the multi-sided markets. They are frequently seen as innovations that provide users or business participants the possibility of immediate communication (Gawer and Cusumano, 2014). The smartphone has brought several changes into the business context, many technology companies being forced to adapt or change their business model to a platform-based model, as people interact with each other, solve their problems, and take their information exclusively with the help of the internet. Therefore, researchers attempted to analyze the impact and performance drivers of various types of platforms (Steininger et al., 2013; Taeuscher and Laudien, 2018). However, due to its complexity, the technology industry faces different challenges in terms of individual business success; consequently, businesses rely on the skills and experience of external partners to develop their competitive advantage (Lindgren et al., 2010, Frery et al., 2015). On the other hand, studying the concept through the lens of technology management, a platform is defined as a technology that enables transactions between a partner network and users that inevitably become interdependent collaborators in an ecosystem (Adner, 2017). How can a platform business model manage the competition battle? The answer lies mainly in how the company chooses to invest in new technologies, either by acquiring new businesses or by innovating the existing model based on their internal capabilities (Zhao et al., 2019). Several features of business model innovation have been studied over time, as this constitutes an emerging field of research that gained great popularity among both academics and business professionals. The focus has always been on the debate on when a business model change may be called an innovation (Chesbrough, 2007) or drivers for such initiatives (de Reuver et al., 2009; Mezger, 2014). The innovation management literature presents general themes that contribute to a better understanding of business models within the digital era such as open innovation, business model capabilities, customer-oriented business models, industry dynamics and business model innovation (Maucuer and Renaud, 2019).

The Internet is the most suitable environment to research business evolution (Wirtz et al., 2010). Several business model innovations can be differentiated within the business model literature. It is stated that innovations in the business model are capable of generating higher returns than product or process innovations (Chesbrough, 2007; Lindgardt et al., 2009). This is why innovating the business model does not necessarily determine new products or services, but it creates new approaches to create value (Yang et al., 2017). New concepts have been developed such as business model transformation - when the existing business model is being transformed into another business model; business model diversification - when the existing business model prevails, but it helps putting in place an additional business model and business model acquisition - when a new business model is acquired and then incorporated into the existing business model (Geissdoerfer et al., 2018). However, there has been less previous evidence for technology acquisitions being studies directly related to platform business models. Nonetheless, there is confirmation that acquiring new technology companies may represent an essential component of the innovation strategy of many established companies (Dowie et al., 2017). A platform requires continuous access to new technologies and complementary capabilities in order to establish a strong competitive advantage. Consequently, a company may strategically gain new resources and tacit knowledge by making such a technology investment, and at the same time it may also increase the market power and establish business in another geographic area (Graebner et al., 2010).

\section{Methodology}

This paper analyzes different platform approaches based on a multi-case analysis across the technology industry. Developing insights on platform business models, the study explores the issue through the lens of business model innovation, when technology acquisitions are made in order to increase the user base. The methodology adopted in this research work is exploratory and the multiple case study is used as the main approach. This has been utilized by a great number of authors studying the business platforms (Wonglimpiyarat, 2012; Taeuscher and Laudien, 2018). Moreover, as Yin (1994) states, this methodological approach makes it possible for the researchers to investigate the data both within each particular situation and across situations. The case study analyzes different platform business models as a unit of analysis of the five big tech companies. This may be helpful in identifying patterns in the technology industry as well as shedding light on previously hidden issues. Moreover, integrated case study approaches that take into consideration the entire network of participants in shared innovation strategies are preferred when studying platform businesses (de Reuver et al., 2017).

This study will take advantage of the opportunity to collect data from various contexts in order to gain further understanding of the studied phenomenon. Five case companies are chosen for this research: Microsoft, Apple, Amazon, Google, and Facebook. In the first place, they were chosen as all five companies have been subject of interest to several research works addressing the platform concept (Serkan, 2013; Plantin et al, 2016; Sadq et al, 2018; Ulrich, 2017). Moreover, they are reported as major strategic actors in the technology industry by several sources (Harvard Business Review, Bloomberg, The economist, Forbes, Reuters, Financial Times). Secondly, the 
selected companies are strongly competitive in terms of market capitalization and they are listed in the top five NASDAQ index (Press, 2018). As a result, there is a considerable amount of publicly available information. In addition, these companies have developed their businesses through strategic acquisition during the past decade. As the technology acquisitions may have the potential to provide relevant perspectives on how they establish and preserve their market influence, this is an important element for the case study analysis. Third, the chosen technology companies may demonstrate great abilities to compete with international players of innovation, as they have a great exposure to the international market. From this point of view, companies are also selected based on their implication level in emerging industries to develop future products or services, as the technology sector relies mostly on innovation.

In the initial phase of the research, the content analysis method was used on existing publications that discussed several types of platform business models. We have developed a coding protocol that determined specific businessrelated dimensions regarding company size, core business model, mission and vision, business acquisitions as well as existing and developing products and services. With the purpose of gaining a detailed perspective of the cases, the keyword search was used in order to collect the data on all five companies from a wide spectrum of publicly available sources: annual reports, company newsletters, industry reports, other case-studies and conference or discussion papers. Document analysis was used as a qualitative research method. As a deliberate technique for reviewing company's available reports, this has been used to gain a comprehensive understanding about each company's business development context and further develop empirical knowledge (Bowen, 2009). The use of multiple sources allowed the authors to approach various sides of the issue. These sources were found in electronic academic databases (Springer, Elsevier, Google Scholar, Wiley Online Library), companies electronic newsroom archives (Microsoft Press, Apple Newsroom, Amazon Press Center, Facebook Data Center, Google Press room) as well as libraries (Central University Library "Carol I", Bucharest and National Library of Romania). The data supporting the case study findings are available within the article's supplementary materials available from the corresponding author C-A S., upon request.

\section{Case study}

The Covid-19 crisis has seriously changed the technology landscape. Online education, e-commerce, e-logistics, software as a service and fintech are the main areas where technological innovations took place in 2020. Access to new products and services accelerated business model innovations (IFC, 2020). It is clearer that technology is the key strategic competitive factor in terms of how companies and ecosystems work. Technology industry is the one that can recover faster than other business industries because there are many opportunities that can enhance a company's ability to innovate the existing business model or to create a new one. Companies were forced to learn as soon as possible the new individuals' needs and to adapt to new ways of doing business. People were seeking rapid solutions for in-person business meetings or classroom activities, therefore companies started to build virtual formulas in order to accommodate the new global needs. Moreover, the Covid-19 crisis allowed companies to develop new collaboration tools between humans and artificial intelligence, thus new innovation domains have emerged such as 'DARQ technologies': distributed ledgers, artificial intelligence, extended reality, and quantum computing (Accenture, 2020). One of the main priorities for tech leaders is the strategy on mergers and acquisitions (McKinsey, 2020). The companies selected for this case study have developed over the years a series of platform business models which were later expanded through strategic technological acquisitions.

\subsection{The Software Platform}

Microsoft is the company that entered the software market since 1985, when the operating system Microsoft Windows was launched. Since its strategy counts on internal innovations, the development of products and services takes place mainly within the organization, in this way preserving competitive advantage and product flexibility. Microsoft's main goal was to provide everything necessary for running a personal computer. Its software was always upgraded through acquiring other software companies like NextBase, Vermeer Technologies or GiftHub. Being a developer-focused company, these acquisitions define the company strategy to create technology in order to enable others to create technology as well. Therefore, the core source of revenue is its partner ecosystems, as a broad range of hardware sellers choose to integrate its software solutions with their own offerings. As the vision of the company was always directed towards a modern workplace, Microsoft focused on improving the accessibility of real-time video and voice communications. This was possible through acquiring Skype, a telecommunication application with 170 million connected users that was shortly integrated with its existing software products. Skype for Business and Microsoft Teams were further developed as communication and collaboration platforms. In the business environment, there is always a need to invest in hardware and software platforms in order to meet customer demands and implement new products and services in a more efficient way (KPMG, 2020). Platform businesses are now connecting governments, individuals, and businesses across the globe 
(IFC, 2020). Therefore, in terms of software innovation strategy, Microsoft reinvented productivity and built a digital transformation platform for organizations that wanted to use digital technologies as a solution for business transformation. In addition, the company expanded its productivity-centered business model with a completely different acquisition: the social media platform LinkedIn. This agreement brought the company the opportunity to further enlarge its productive workplace vision through connecting on a platform with companies, employees, and job seekers. During the global health crisis, LinkedIn was used by Microsoft to offer free online courses for everyone who wanted to acquire digital skills or new extra tools that made it possible for all persons that lost their job to find a job transition based on a skills similarity tool. Moreover, this company is also a good example of value co-creation. Its business model relies on a product adaptation approach from the customer's feedback. New services are developed continuously in order to improve its software applications based on the community of users and engineers (Romero and Molina, 2011). Another example of a successful software business model may be found in Google's story of doing business. Built with an open-source approach, Google developed Android, its software platform, with the main objective of expanding its ecosystem quickly and efficiently. The main business model of Google implies the growth of advertising revenues and this requires as much scale as possible (Kimmo et al., 2020). Moreover, with the development of Android, a mobile operating system based on an open-source software, Google could build its own digital goods platform through Google Play Store. Digital openness is a key feature of a successful platform strategy, as it may influence how the platform business takes a competitive advantage from its external users' resources (Thomas et al., 2014). A platform initiative to allow access and authority to suppliers, developers, and customers it is considered on one hand a strategy with the potential of bringing a rapid success but on the other hand, a strategy with high risks (Broekhuizen et al., 2019). Amazon was seriously taking advantage of the open-source software business model of Google to develop at a low cost the core technology for Amazon Fire and compete directly with Google (Kimmo et al., 2020). This is a good example on how a company may replicate and adapt its platform business model following the example of a market competitor. The software platform gained popularity within the technology industry also due to various strategies of Apple. The company is creating value through its consumer electronics integrated within its operating system and productivity software. Until the 2000s, Apple invested in its software platform through the technology acquisition NeXT Computer, strengthening its operating system foundation. Furthermore, the company made several strategic acquisitions in 3D technology through C3 Technologies and PrimeSense, facial recognition software - Polar Rose or artificial intelligence through iKinema and Sensomotoric Instruments - motion capture technology and computer vision with the main intention to incorporate them into its software platform, Apple iOS. In contrast with Google's open approach, Apple has adopted a much stricter attitude and managed differently the developers' presence on its platform. But, as Google was entering the market after Apple launched its software, the company had to embrace different control strategies for its Android platform in order to secure its profits (Kimmo et al., 2020).

\subsection{The Hardware Platform}

Technological ecosystems have had to go through several under pressure innovation tests during the period of global health crisis and thus, companies needed to work together and find quick solutions to stop the spread of the virus or improve people's lives (Accenture, 2020). It is fundamental to prove an innovative behavior in order to stay competitive in the technology business environment (Calabrese et al., 2013). The Apple CEO's aspiration of doing business completely different from competitors drove the company towards a radical industrial design of its hardware platform, which unquestionably characterized Apple's access to the electronic consumer market. The hardware business model of Apple is being represented by its products Mac, iPad, iPhone and iWatch. As the digital era came with different challenges within the technology industry, Apple took a proactive approach to invest in augmented reality and machine learning platforms. Machine learning uses algorithms in order to learn from existing data and it is largely being applied to market analysis and image recognition (Li et al., 2017). Augmented reality is being embedded into platforms in order to have a better information visualization. They use different types of digital or hologram optics - hologram being a mix between real world and virtual objects (Alcacer and Cruz-Machado, 2019). For example, Metaio, an augmented-reality software was used by Apple to design its hardware and software for delivering the best augmented-reality experience for its customers. Apple has integrated all these acquisitions within its platform in order to be able to offer its customers devices with advanced cameras, motion sensors and powerful graphic processors. A consolidative strategy to deliver new customer value proposition through a technology investment may consist in deploying dynamic capabilities in order to innovate the business model (Čirjevskis, 2019). The use of virtual reality has expanded lately, and travel experiences have been replaced with VR headsets to explore new destinations in the virtual world. Virtual reality is a technology trend that is shaping the outlook of human interactions (Forbes, 2020). People need new digitalized processes that support the good functioning of today's world; therefore, platform leaders need to develop customer-centric and location independent solutions (Gartner, 2020). A good example of a company that took advantage of these new 
technologies in order to innovate its business model is Facebook. The company acquired Oculus VR in 2015, a technology company specialized in virtual reality. Then, in a short time, Facebook invested in facial analysis software through Faciometrics and neural interface technology through CTRL-labs in 2019. These investments made Facebook able to develop its hardware business model around the Oculus device using a long-term approach over the value creation process. In terms of artificial intelligence investments, the technology industry hosts the strategic presence of Amazon, a company that has been developing its hardware platform since 2007, when Amazon Kindle was launched. But later the company focused on different technology acquisitions related to smarthome technology and robotics. Amazon wanted to enhance its smart home offerings like Amazon Alexa and Amazon Echo.

\subsection{The Infrastructure Platform}

The fourth industrial revolution is based on three main technology dimensions: digital (for example: internet of things, artificial intelligence, machine learning, big data, cloud computing and digital platforms), physical (for example: autonomous cars, 3D printing) and biological (ex.: neurotechnology) (Li et al., 2017). In addition to the multitude of strategies to boost platform business models, companies are now facing several challenges regarding cybersecurity and their work is being focused on how they can ensure their cloud data is secured (Deloitte, 2021). Cloud computing made possible the development of infrastructure as a service, platform as a service and software as a service (Alcacer and Cruz-Machado, 2019). The cloud plays an essential role in developing Microsoft's platforms. The predictive technology acquired through SwiftKey, a virtual keyboard application, offered the opportunity to leverage the intelligent cloud. Moreover, the company centered its investments around business analytics. Increasing its capability in organizational analytics, artificial intelligence, and multi-cloud management through companies like VoloMetrix, Metanautix and Cloudyn, Microsoft innovated its infrastructure platform through the capabilities acquired from other technology companies. Its platform is represented by Microsoft Azure that offers its clients cloud storage capacity and to the company a competitive advantage through the creation of its own technology solutions. But the first to introduce an infrastructure platform among the big five technology companies was Amazon, in 2006 with Amazon Web Services. The platform attracted many customers as it was particularly helpful to develop online retailing applications (Cusumano et al, 2019). Sharing the use of the cloud with others was a practical way to improve the profitability of its business model as third parties could make a contribution to the innovation investment. As for the infrastructure platform of Google, launched through Google Cloud Platform, it could not establish the same competitiveness as Amazon Web Services or Microsoft Azure, as it was a domain in which the company did not have enough business experience. However, Google is growing its cloud computing platform and intends to follow the trends within the technology industry. Google Cloud is offering diverse services in security, machine learning, networking, data analytics, operations, developer, and management tools with no dependence on location.

\subsection{The Advertising Platform}

During the Covid-19 global crisis the need for innovation was greater than any other time before and this context forced companies to update their business models in order to keep up with the new market requirements (Accenture, 2020). The use of artificial intelligence addresses key business demands and helps companies to transition to a platform business model (Grewal et al., 2020). Now, information and data security are essential for the success of the technology industry (Alcacer and Cruz-Machado, 2019). The Internet of things offers limitless possibilities in terms of business optimization, as it merges artificial intelligence, data analytics, networks, and people (Alcacer and Cruz-Machado, 2019). Research presents several innovation drivers that make a company be distinguished, among others. In order to improve their current business, companies need to have a qualified and experienced workforce that master the requirements of new technologies, bring innovation efforts on the table and encourage the network effects to take place (Calabrese et al., 2013). Google began its journey as a technology company based on the internet search and advertising business and it has developed its own platform business model over time. The search service is provided to its customers and the customers provide information that is sold to advertisers. The company was an early innovator in online advertising, and its platform business model includes AdWords, AdSense AdMob. To improve its online advertising model, Google acquired innovation from several businesses. For example, the company invested in software applications for online advertising and internet traffic analysis technology through Applied Semantics and Keyhole. Moreover, by buying Akwan Information Technologies, Google displayed a strategic thinking as this helped the company establish a new advertising market in Latin America and open new operation centers. One of the biggest investments was DoubleClick, a company that developed and provided Internet ad serving services. Following this trend, other businesses with strong expertise in predictive analytics such as Skybox Imaging or Apigee, or Trendalyzer, an information visualization software, helped Google introduce its new platform, Google Marketing Platform. Global IP Solutions, a technology 
company specialized in real-time voice and video processing software for IP networks, assisted Google to keep up with the technological trend of using real-time digital tools. The main strategy was to merge the advertising platform with an analytics platform in order to achieve smarter marketing and deliver better solutions for its customers. In addition, Google introduced Google Ad Manager, an integrated advertising management platform. Therefore, the company used to invest in new digital technologies and then integrate them into its own services. Its effective business solutions were also offered to governments or healthcare systems during Covid-19 pandemic in order to develop new epidemiological models, to monitor the spread of the virus or to provide real-time information.

\subsection{The Social Networking Platform}

The practices of Merger \& Acquisition represent one of the ways of improving overall technical efficiency, which would later be converted into higher profits. The Internet of things has grown since mobile devices became indispensable to people. IoT makes it possible to connect anything, anytime (Alcacer and Cruz-Machado, 2019). Online media consumption has significantly increased in 2020, thus there was an increasing demand for streaming services, social media platforms and any virtual content platform (Forbes, 2020). The social media platforms influence consumer behavior and retailing services are using these types of platforms in order to better serve their customers (Grewal et al., 2020). The human interaction in the virtual world implies a great number of participants which create a big amount of content. Implicitly, they are participating in the value creation process through the user-added value: user-generated content and user-generated creativity (Wirtz et al., 2010). Facebook does not have the extensive experience of the other technology companies; however, its business was built differently, around a social networking value proposition. Its platform business model is user-data centered and in terms of profitability it is the most successful, as its users are providing their content for free; therefore, there are no costs of goods sold. The value is captured by charging the advertisers that want access to the company's user database. The company tried to bring variety to its platform business model through investments in other social media businesses like FriendFeed, ConnectU, Sharegrove, Instagram and Tactile. In order to transform its networking applications like Messenger and Whatsapp into wider social media platforms, the company invested in other digital technologies to develop a proper infrastructure. This is how e-commerce and online payments have taken center stage on Facebook's tactics, as the company wants to develop Whatsapp Payments, a platform that will allow transactions as fast as sending a photo. In terms of Covid-19 support, as a social media platform, Facebook needed to take a big responsibility to ensure its community has access to reliable information. Therefore, initiatives against misinformation were taken through banning exploitative tactics in online advertising on its platforms. In addition to this, Facebook, Messenger and Whatsapp were the best available platforms that made it easier for people to connect and request or offer help during the coronavirus health crisis.

\subsection{The E-Commerce Platform}

New shopping solutions such as virtual fitting rooms and new payment technologies are at the core of platform business models that emerged during Covid-19 pandemic (Forbes, 2020). The technology industry has changed from many perspectives due to diverse consumer demands and behaviors changed due to the new context in which the people had to learn to live. The self-service solutions gained huge popularity, as authorities have introduced rules of social distancing and they have created new functional rules for the society. Moreover, e-commerce became rapidly the sole method of buying and selling goods and services during quarantine periods (Forbes, 2020). This has made it possible for smaller companies to enter the market or for the big technology giants to innovate their business models and create indispensable digital services. The e-commerce business model relies mainly on the Internet for the payment and delivery aspects of the trade (Wirtz, 2010). One of the best examples that illustrates a successful digital retail platform is Amazon. The company owns online, and physical stores and its business strategy focused on further developing both. The early technology adopters may have the power to change the rules of how business is conducted (Grewal et al., 2020). Amazon invested in new technologies in order to be able to innovate its products and services. In order to extend its platform, the company acquired other online retailers as Zappos, an online clothing retailer or Pillpack, an online pharmacy and the multinational supermarket chain Whole Foods. As the company's value proposition is mainly customer-centric, this helped Amazon innovate its ecommerce platform business model and build a community platform where customers can interact, write products reviews, and send recommendations. Moreover, in order to offer a new experience and improve its value proposition to its customers, Amazon wants to transform its delivery system through drone technology. This will obviously make Amazon a first mover in the e-commerce industry, gaining a strategic competitive advantage by offering to its clients a new innovative service (Welch, 2015). This may be a future trend in the technology industry, as collaborative robots introduce new business innovation designed to manage the interaction between humans and new technologies (Alcacer and Cruz-Machado, 2019). Amazon is one of the best examples of early technology 
innovators, as the company has been focused on robotic technologies to reduce costs and give assistance to their workers as well as to experimenting new business approaches such as drone delivery or predictive analytics capabilities (Grewal et al., 2020). As a response to Covid-19 challenges, Amazon invested in artificial intelligence to improve workplace safety, make serious investments for supporting supply chain recovery, was creating new partnerships with other organization to help its suppliers overcome the uncertainties coming from the new context of work and offered its delivery service to food banks in America to help the families in need.

\section{Discussion and Conclusion}

Technology solutions are needed to help the world overcome Covid-19 challenges, therefore companies from the technology industry need to innovate their platform facilities. Businesses are looking for cloud-based services that can reduce their costs (Deloitte, 2021). People are using their mobile devices more and more to access health care services and manage their health care (WEF, 2020) The e-commerce, remote work and online learning tools have been the main aspects of the digital environment that made the most technological advancements during the Covid19 crisis. Platform providers are building new capabilities to support remote learning, teaching, and working (Deloitte, 2020). Another trend of the business world that it is here to stay even after the pandemic ends is related to remote working practices. This new technological trend has made possible the development of videoconferencing platforms, team collaboration software, scheduling software for remote teams or project management software. Companies are trying to build recovery strategies for Covid-19 period which will imply unprecedented communication and orchestration business measures together with new tools and resources addressing stress and mental health problems (Deloitte, 2020).

In conclusion, this research paper came up with implications for different types of platform business models as a result of the selected companies' analysis. First, all the business platforms innovated their business model several times from the creation till the maturity level. Second, business model innovation was realized through technology acquisitions around the core business of the company. There is a distinction between technology acquisitions that are performance-focused or functionality-focused (Stein and Joachim, 2018). When platform businesses decide to take an open approach and be open to new partnerships with the external environment, they will easily facilitate mutual exchanges between them. As this is the case of how Google managed its entrance in the software platform market, its new approach promoted an ongoing innovative strategy. In addition, the creation of a technology ecosystem is important for doing business in the digital age, given the dynamic technology environment, as stakeholders need to communicate with one another in order to nurture innovation. Amazon is a good example on how a company may replicate and adapt its platform business model following the example of a market competitor. Nonetheless there may be other ways to attract users on a platform, for example through acquiring another platform's user base (Overbeek, 2018). Being a developer-focused company, Microsoft acquired new platforms in order to reinvent the productivity concept and built an entire digital transformation platform for organizations that wanted to use digital technologies as a solution for business transformation. A business platform can evolve through adding extra features from its external partners and expanding the technology ecosystem around the platform (Tiwana, 2014). Facebook acquired other social media platforms in order to expand its existing user-data centered platform and in terms of profitability it is the most successful, as its users are providing their content for free; therefore, there are no costs of goods sold.

The technology industry has the power to reshape the new world of business through building entire ecosystems around different products and services. Technology companies are fully embracing the co-creating approach as customers, suppliers and partners are actively participating in the value creation process and consequently, they begin to co-create. The digital platforms brought a new type of economic relations and they are continuously being innovated in an interconnected business environment. Therefore, as the future remains open to new innovations, the value must be co-created and co-delivered. This research study is subject to limitations, as the main data used for the case study was derived from secondary sources and it provided insights about each company's platform business model from a macro perspective. Future research may need to investigate how the new trends created within the technology industry may influence the development of new platform business models.

\section{Acknowledgments}

An earlier version of this paper was presented at the 16th European Conference on Management, Leadership and Governance, October 26-27, 2020, hosted by ACI and EM-Normandie Business School, Oxford, UK. We thank reviewers and participants for their feedback. Author contributions: conceptualization and methodology C.-A. S. and D. T., writing - original draft preparation, review and editing C.-A.S.

\section{References}

Accenture (2020). COVID-19: Post-Coronavirus technology trends. https://www.accenture.com/cz- 
en/insights/technology/tech-vision-coronavirus-trends

Adner, R. (2017). Ecosystem as structure: An actionable construct for strategy. Journal of Management, 43(1), 3958. https://doi.org/10.1177/0149206316678451

Afuah, A. (2004). Business Models: A Strategic Management Approach. McGraw- Hill/Irwin, Boston.

Alcacer, V., \& Cruz-Machado, V. (2019). Scanning the Industry 4.0: A Literature Review on Technologies for Manufacturing Systems. Engineering Science and Technology, an International Journal, 22(3), 899-919. https://doi.org/10.1016/j.jestch.2019.01.006

Boons, F., \& Lüdeke-Freund, F. (2013). Business models for sustainable innovation: state-of-the-art and steps towards a research agenda. Journal of Cleaner Production, 45, 9-19. https://doi.org/10.1016/j.jclepro.2012.07.007

Bowen, G. A. (2009). Document Analysis as a Qualitative Research Method. Qualitative Research Journal, 9(2), 27-40. https://doi.org/10.3316/QRJ0902027

Broekhuizen, T. L. J., Emrich, O., Gijsenberg, M. J., Broekhuis, M., Donkers, B., \& Sloot, L. M. (2019). Digital platform openness: Drivers, dimensions and outcomes. Journal of Business Research, 122, 902-914. https://doi.org/10.1016/j.jbusres.2019.07.001

Calabrese, A., Campisi, D., Capece, G., Costa, R., \& Di Pillo, F. (2013). Competiveness and Innovation in Hightech Companies: An Application to the Italian Biotech and Aerospace Industries. International Journal of Engineering Business Management, 5, 40. https://doi.org/10.5772/56755

Casadeus-Masanell \& Ricart, J. E. (2011) How to Design A Winning Business Model. Harvard Business Review. Retrieved from http://www.bmg-businessconsulting.com/wp-content/uploads/2012/09/How-to-Redesign -AWinning-Business-Model.pdf

Chesbrough, H. (2007). Business model innovation: It's not just about technology anymore. Strategy and Leadership, 35(6), 12-17. https://doi.org/10.1108/10878570710833714

De Reuver, M., Sørensen, C., \& Basole, R. C. (2017). The digital platform: a research agenda. Journal of Information Technology, 33(2), 124-135. https://doi.org/10.1057/s41265-016-0033-3

De Reuver, M., Bouwman, H., and MacInnes, I. (2009). Business model dynamics: A case survey. Journal of Theoretical and Applied Electronic Commerce Research, 4(1), 1-11. https://doi.org/10.4067/S071818762009000100002

Deloitte (2020) COVID-19: Shaping the Future Through Digital Business. Retrieved from https:/www2.deloitte.com/content/dam/Deloitte/global/Documents/About-Deloitte/COVID-19/gxtechnology-digital-COVID-19-recovery-shaping-future-digital-business.pdf

Deloitte. (2021), 2021 outlook for the US technology industry. Retrieved from https:/www2.deloitte.com/us/en/pages/technology-media-and-telecommunications/articles/technologyindustry-outlook.html/

Dowie, J., Henningsson, S., Kude, T., and Popp, K. (2017). Merging Platform Ecosystems in Technology Acquisitions: A Governance Perspective, Proceedings of the 25th European Conference on Information $\begin{array}{lllll}\text { Systems } & \text { (ECIS } & \text { 2017), } & \text { Retrieved }\end{array}$ http://aisel.aisnet.org/cgi/viewcontent.cgi?article=1145\&context=ecis2017_rp

DXC. Technology (2021). Technology: Industry Overview. Retrieved from https://www.dxc.technology/technology/insights/145881-technology_industry_overview

Eckhardt, J. T., Ciuchta, M. P., \& Carpenter, M. (2018). Open innovation, information, and entrepreneurship within platform ecosystems. Strategic Entrepreneurship Journal, 12(3), 369-391. https://doi.org/10.1002/sej.1298

Frery, F., Lecocq, X., \& Warnier, V. (2015). Competing with ordinary resources. MIT Sloan Management Review, 56(3), 68-77. Retrieved from https://sloanreview.mit.edu/article/competing-with-ordinary-resources/

Press, G. (2018). How Apple, Amazon, Facebook, Google and Microsoft Made 2018 The Year That IT Mattered A Lot. Forbes. Retrieved from https://www.forbes.com/sites/gilpress/2018/12/30/how-apple-amazonfacebook-google-and-microsoft-made-2018-the-year-that-it-mattered-a-lot/

Forbes. (2020). 16 Pandemic-Driven Tech Trends That Are Here To Stay. Retrieved from https://www.forbes.com/sites/forbestechcouncil/2020/10/19/16-pandemic-driven-tech-trends-that-are-hereto-stay/?sh=7ebdd70f $2 \mathrm{~d} 12$ 
Gartner. (2020). Gartner Top Strategic Technology Trends for 2021. Retrieved from https://www.gartner.com/smarterwithgartner/gartner-top-strategic-technology-trends-for-2021/

Gawer, A., \& Cusumano, M. A. (2014). Industry Platforms and Ecosystem Innovation. Journal of Product Innovation Management, 31(3), 417-433. https://doi.org/10.1111/jpim.12105

Graebner, M., Eisenhardt, K., \& Roundy, P. (2010). Success and Failure in Technology Acquisitions: Lessons for Buyers and Sellers. Academy of Management Perspectives, 24, 73-92. https://doi.org/10.5465/amp.24.3.73

Grewal, D., Hulland, J., \& Kopalle, P. K. (2020). The future of technology and marketing: a multidisciplinary perspective. Journal of the Academy of Marketing Science, 48, 1-8. https://doi.org/10.1007/s11747-01900711-4

Geissdoerfer, M., Vladimirova, D., \& Evans, S. (2018). Sustainable business model innovation: A review. Journal of Cleaner Production, 198, 401-416. https://doi.org/10.1016/j.jclepro.2018.06.240

International Finance Corporation. (2020) The Impact of COVID-19 on Disruptive Technology Adoption in Emerging Markets. Retrieved from https://www.ifc.org/wps/wcm/connect/537b9b66-a35c-40cf-bed8-6f6 18c4f63d8/202009-COVID-19-Impact-Disruptive-Tech-EM.pdf?MOD=AJPERES\&CVID=njn5xG9

Johnson, M. W., Christensen, C. M., \& Henning, K. (2008). Reinventing Your Business Model. Harvard Business Review. Retrieved from https://hbr.org/2008/12/reinventing-your-business-model

Karhu, K., Gustafsson, R., Eaton, B. Sørensen, C., \& Henfridsson, O. (2020). Four Tactics for Implementing a Balanced Digital Platform Strategy. MIS Quarterly Executive, 19(2). 105-120. https://doi.org/10.17705/2msqe.00027

Karhu, K., \& Ritala, P. (2020). Slicing the cake without baking it: Opportunistic platform entry strategies in digital markets. Long Range Planning, https://doi.org/10.1016/j.lrp.2020.101988.

KPMG. (2020) Technology industry CEO outlook. Retrieved from https://assets.kpmg/content/dam/kpmg/xx/pdf/2020/10/technology-industry-ceo-outlook.pdf

Lindgren, P., Taran, Y., \& Boer, H. (2010). From single firm to network-based business model innovation. International Journal of Entrepreneurship and Innovation Management, 12(2), 122-137. https://doi.org/10.1504/IJEIM.2010.034417

Lindgardt, Z., Reeves, M., Stalk, G., \& Deimler, M. S. (2009). Business Model Innovation. When the Game Gets Tough, Change the Game. The Boston Consulting Group, Boston. Retrieved from https://imagesrc.bcg.com/Images/BCG_Business_Model_Innovation_Dec_09_tcm56-121706.pdf

Li, G., Hou, Y., \& Wu, A. (2017) Fourth Industrial Revolution: technological drivers, impacts and coping methods. Chinese Geographical Science, 27, 626-637. https://doi.org/10.1007/s11769-017-0890-x

Maucuer, R., \& A. Renaud (2019). Business Model Research: A Bibliometric Analysis of Origins and Trends, Management, 22(2), 176-215. https://www.cairn.info/revue-management-2019-2-page-176.htm?ref=doi

McKinsey. (2020) The technology industry in 2020 and beyond. Retrieved from https://www.mckinsey.com/industries/technology-media-and-telecommunications/our-insights/thetechnology-industry-in-2020-and-beyond\#

Mezger, F. (2014). Toward a Capability-based Conceptualization of Business Model Innovation: Insights from an Explorative Study. $R \&$ D Management, 44(5), 429-449. https://doi.org/10.1111/radm.12076

Morris, M., Schindehutte, M., \& Allen, J. (2005). The entrepreneur's business model: toward a unified perspective. Journal of Business Research, 58(6), 726-735. https://doi.org/10.1016/j.jbusres.2003.11.001

Osterwalder, A., Pigneur, Y., \& Tucci, C. (2010). Clarifying Business Models: Origins, Present, and Future of the Concept. Communications of AIS, 16. https://doi.org/10.17705/1CAIS.01601

Parker, G. G., \& Van Alstyne, M. W. (2018) Innovation, openness, and platform control. Management Science, 64, 2973-3468. https://doi.org/10.1287/mnsc.2017.2757

PwC. (2017). Sizing the prize: What's the real value of AI for your business and how can you capitalise? Retrieved from https://www.pwc.com/gx/en/issues/analytics/assets/pwc-ai-analysis-sizing-the-prize- report.pdf

Plantin, J. C., Lagoze, C., Edwards, P. N., \& Sandvig, C. (2016). Infrastructure studies meet platform studies in the age of Google and Facebook. New Media \& Society, 20(1), 293-310. https://doi.org/10.1177/1461444816661553 
Rasmussen, B. (2007). Business Models and the Theory of the Firm. Working Paper. Victoria University of Technology, Melbourne, Australia. Retrieved from http://vuir.vu.edu.au/id/eprint/15947

Romero, D., \& Molina, A. (2011). Collaborative Networked Organisations and Customer Communities: Value CoCreation and Co-Innovation in the Networking Era. Production Planning \& Control, 22. 447-472. https://doi.org/10.1080/09537287.2010.536619

Sadq, Z., Nuraddin, S., \& Saeed, H. (2018). Analyzing the Amazon success strategies, Journal of Process Management. New Technologies, 6, 65-69. https://doi.org/10.5937/jouproman6-19264

Serkan A. (2013). Two-Sided Markets: Apple's Digital Application Platform. Journal of Social Science Research, l(1). https://doi.org/10.24297/jssr.v1i1.3053

Steininger, D. M., Wunderlich, P., \& Pohl, F. (2013). Exploring Competitive Advantage of Social Networking Sites: A Business Model Perspective. ECIS 2013 Proceedings, paper 214. Retrieved from https://aisel.aisnet.org/ecis2013_cr/214.

Taeuscher, K., \& Laudien, S. M. (2018). Understanding platform business models: A mixed methods study of marketplaces. European Management Journal, 36(3), 319-329. https://doi.org/10.1016/j.emj.2017.06.005

Teece, D. (2010). Business Models, Business Strategy and Innovation. Long Range Planning, 43(2e3), 172-194. https://doi.org/10.1016/j.lrp.2009.07.003

Teece, D. J. (2018). Business models and dynamic capabilities. Long Range Planning, 51(1), 40-49. https://doi.org/10.1016/j.lrp.2017.06.007

Tiwana, A. (2014). The Value Proposition of Platforms. Platform Ecosystems in Platform Ecosystems. Morgan Kaufmann. Retrieved from https://static1.squarespace.com/static/5ba7b499755be22c410b1cae/t/5d619cf1 4aa7270001322054/1566678272862/Platform+Ecosystems.pdf

Ulrich D. (2017). Apple, Amazon, Google, Facebook, Microsoft: Market concentration - competition - innovation strategies. Universität Stuttgart, SOI Discussion Paper No. 2017-01.

Wonglimpiyarat, J. (2012). Technology strategies and standard competition - Comparative innovation cases of Apple and Microsoft. The Journal of High Technology Management Research, 23(2), 90-102. https://doi.org/10.1016/j.hitech.2012.06.005

Wirtz, B. W., Schilke, O., \& Ullrich, S. (2010). Strategic Development of Business Models. Long Range Planning, 43(2-3), 272-290. https://doi.org/10.1016/j.lrp.2010.01.005

Wirtz, B. W., Pistoia, A., Ullrich, S., \& Göttel, V. (2016). Business Models: Origin, Development and Future Research Perspectives. Long Range Planning, 49(1), 36-54. https://doi.org/10.1016/j.lrp.2015.04.001

World Economic Forum. (2020) 3 ways tech solutions can help the world weather COVID-19. Retrieved from https://www.weforum.org/agenda/2020/11/3-ways-new-technology-solutions-can-help-the-world-fightcovid-19/

Yang, M., Evans, S., Vladimirova, D., \& Rana, P. (2016). Value uncaptured perspective for sustainable business model innovation. Journal of Cleaner Production. 140(3), 1794-1804. https://doi.org/10.1016/j.jclepro.2016.07.102

Yin, R. K. (1994). Case study research - Design and Methods, Sage Publications.

Zhao, Y., Von Delft, S., Morgan-Thomas, A., \& Buck, T. (2019). The evolution of platform business models: Exploring competitive battles in the world of platforms. Long Range Planning, 101892. https://doi.org/10.1016/j.lrp.2019.101892

Zott, C., Amit, R. H., \& Massa, L. (2011). The Business Model: Recent Developments and Future Research. SSRN Electronic Journal. https://doi.org/10.2139/ssrn.1674384

\section{Copyrights}

Copyright for this article is retained by the author(s), with first publication rights granted to the journal.

This is an open-access article distributed under the terms and conditions of the Creative Commons Attribution license (http://creativecommons.org/licenses/by/4.0/). 